\title{
An Influence of Organizational Culture, Motivation and Work Discipline on Performance of Employees at the Center For Forest Area Construction, Region I, Medan
}

\author{
Arpika Sari ${ }^{1}$, Rindi Andika ${ }^{2}$, Hasrul Azwar Hasibuan ${ }^{3}$ \\ 1,2,3Faculty of Social and Science, Universitas Pembangunan Panca Budi, Medan Indonesia \\ Email: arpikasari64@gmail.com
}

\begin{abstract}
This study was conducted to explain the partial or simultaneous influence of organizational culture, motivation, and work discipline variables on employee performance at the Center for Stabilization of Forest Areas Region I Medan. The total population used was 57 respondents consisting of employees who work at the Forest Area Stabilization Center for

Region I Medan, which were taken using a questionnaire that was used as a data collection method in this study. and uses multiple linear regression analysis. The results of the analysis show that there is a simultaneous significant influence between the three variables and a partially significant influence between organizational culture, motivation, and work discipline variables on employee performance at the Forest Area Stabilization Center Region I Medan.
\end{abstract}

Keywords: organizational culture; motivation; work discipline; performance

\section{Introduction}

An organization must be able to optimize its human resources. Human resource management is carried out in order to achieve organizational goals. Employees are the driving force in an organization that has a role in the organization, namely as thinkers, planners and controllers in organizational activities. Because of this, organizations need potential human resource factors, both leaders and employees in the pattern of tasks and supervision which are the determinants of achieving company goals (Mariam, 2016).

Human Resources (HR) is the most important component in a company or organization to run the business it does. Organization must have a goal to be achieved by the organizational members (Niati et al., 2021). Development is a change towards improvement. Changes towards improvement require the mobilization of all human resources and reason to realize what is aspired (Shah et al, 2020). The development of human resources is a process of changing the human resources who belong to an organization, from one situation to another, which is better to prepare a future responsibility in achieving organizational goals

(Werdhiastutie et al, 2020).

With regard to performance, the organizational culture contained in a company also affects the performance that occurs in a company. A good organizational culture will create a good working atmosphere in the company environment. In addition to organizational culture, employees need to be motivated and encourage employees' work passion, so that they are willing to work hard by giving all their abilities and skills to realize company goals (Raditya Priyo et al, 2014). One more thing that affects employee performance is work discipline which is a very important part or variable in the development of human resource management, because discipline in an organization is important, so that there is no negligence, deviation or negligence and finally in doing work. Rivai (2011) states that with high work discipline, it can make it easier for companies to achieve their goals, if employees have work discipline, employees will work effectively and can work time efficiency so that there will be no 


\section{Rowter Journal}

ISSN: 2828-1950 (Online)

\section{Review of Literature}

Employee performance that occurs in the Regional I Medan Forest Area Stabilization Center is considered to be still less than optimal based on the Pre-Survey conducted to 57 employee correspondents in the Medan Region I Forest Area Stabilization Center. The results of the pre-survey questionnaire recapitulation on performance show that currently employees are less motivated to get the best results at work and consider work targets unimportant. This is due to the lack of appreciation or appreciation received from the leadership for the achievement of the good work.

Employee performance is a very important factor for a company. This is because employee performance is a determinant of the success and survival of the company. Therefore, the achievement of company goals completely depends on the human resource factor. Performance is the actual achievement of employees compared to the expected achievements of employees Rahayu (2012). Many factors affect performance, both related to the workforce and related to the company environment and government policies as a whole (Sayogo, 2020).

Factors that affect performance are related to ability, knowledge, work plans, and work motivation (Kasmir, 2016).

Employees can work effectively and comfortably by looking at the conditions of the work environment, from this work environment that can create organizational culture as a shared perception held by members of the organization, a system of mutual understanding. So organizational culture can be defined as what can be done within the company, treat its employees, as well as other organizational operational activities. In addition, the importance of work motivation in increasing a work effectiveness. Because people who have high work motivation will try their best to

An institution or institution is very important to develop an organizational culture. The basis of organizational culture is made on organizational policies, rules of peer communication organizational members in the organizational environment (Permadi, 2017). Organizational culture can also be a characteristic of the organization and must have the participation of leaders and members of the organization (Berliana, 2021). Organizational culture as shared values and norms that exist in an organization and teaches workers who come, organizational culture as a cognitive framework consisting of attitudes, values, behavioral norms and expectations that are shared by members of the organization (Zulfani et al., 2021). Discipline is also very important in an organization, because it is with employee discipline that an organization can achieve the goals of the work program it does. Work discipline is an attitude of respect, respect, obedience and obedience to the applicable regulations, both written and unwritten and being able to carry it out and not evade receiving sanctions if he violates the duties and authorities given to him (Siswanto, 2010). Work discipline is a very important part or variable in the development of human resource management, therefore discipline in an organization is important, so that there is no negligence, deviation or negligence and finally in doing work. Through discipline will reflect strength and success in his work.

There is no appreciation or appreciation for administrations who have high loyalty in their work, and there is no punishment given to administrations who neglect their duties. This results in a decrease in employee motivation to be loyal and do their work on time. Organizational culture factors, motivation and work discipline can be factors that make performance less than optimal 


\section{Research Methods}

Conceptually, organizational culture (X1), motivation (X2), and work discipline (X3) affect the performance (Y) of employees at the Forest Consolidation Center Region I Medan, either simultaneously or partially. The research framework can be described as

follows:

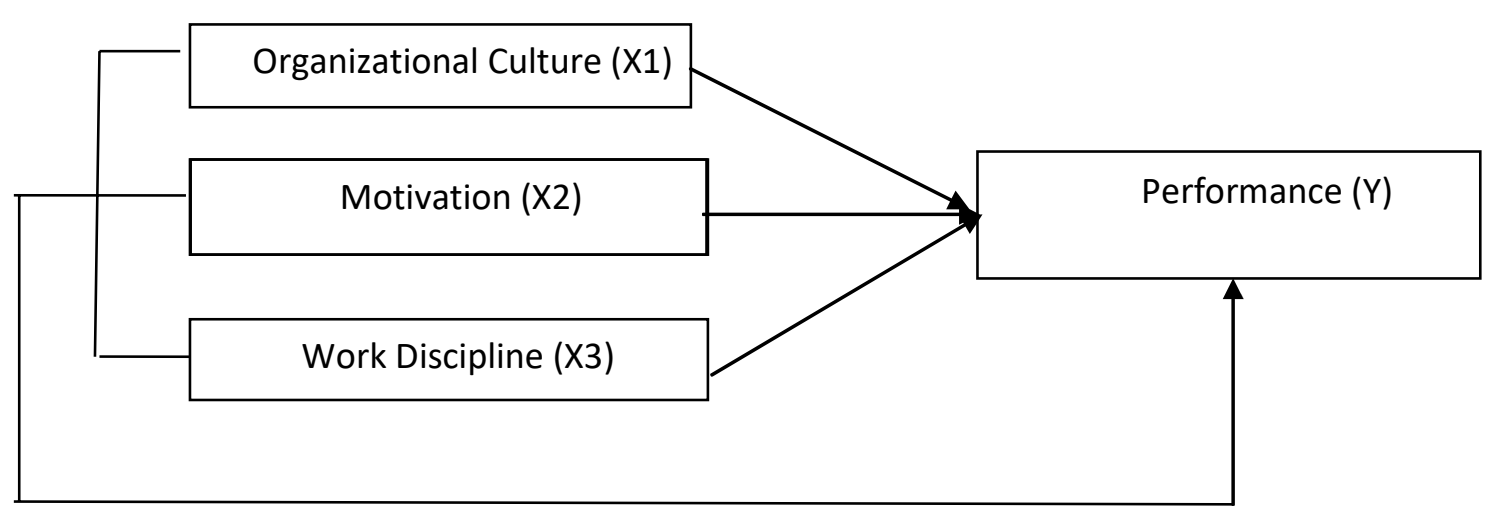

Figure 1. Frame work System

The population in this study were 133 employees at the Forest Area Stabilization Center Region I Medan. While the determination of the number of samples using the Slovin formula.

So based on this formula, the number of samples to be taken is 57 people. The data collection technique used in this research is to use a questionnaire with a Liker scale consisting of 5 alternative answers, namely: Strongly Agree (SS) given a score of 5 Agree (S) is given a score of 4 Disagree (KS) is given a score of 3 Disagree (TS) is given a score of 2 Strongly Disagree (STS) is given a score 1.

After testing the validity, reliability and classical assumption tests (Data Normality Test, Heteroscedasticity Test, and Multicollinearity Test), then the following analysis is carried out.

3.1. Multiple Regression Analysis

To find parameters and constants as well as the values of F-count and t-count, computer assistance will be used with SPSS version 22.00 for windows program. Regression test was used to determine the magnitude of the influence of Organizational Culture (X1), Motivation (X2), and Work Discipline (X3), on the Performance (Y) of Employees at the Center for the Stabilization of Forest Areas Region I Medan. The regression equation is as follows:

$$
\begin{array}{r}
\mathrm{Y}=\mathrm{a}+\mathrm{b} 1 \mathrm{X} 1+\mathrm{b} 2 \mathrm{X} 2+\mathrm{b} 3 \mathrm{X} 3+\mathrm{e} \\
\text { Where: } \\
\mathrm{Y}=\text { Performance } \\
\mathrm{X} 1=\text { Organizational Culture X2 }=\text { Motivation } \\
\mathrm{X} 3=\text { Work Discipline } \\
\mathrm{b} 1=\text { Regression coefficient of Organizational Culture b2 }=\text { Regression coefficient of } \\
\text { Motivation } \\
\mathrm{b} 3=\text { Regression coefficient of Work Discipline } \\
\mathrm{a}=\text { Constant } \\
\mathrm{e}=\text { Error Rate (standard error) }=0.05(5 \%)
\end{array}
$$


F test was conducted to see whether the independent variable; organizational culture (X1), motivation (X2) and work discipline (X3) together on the performance of employees at the Center for Stabilization of Forest Areas Region I Medan. The F test (simultaneous test) is to test whether there is an effect of the independent variables of organizational culture (X1), motivation (X2) and work discipline (X3) simultaneously (simultaneously) on the dependent variable performance $(\mathrm{Y})$.

If the $\mathrm{F}$ test is obtained the value of Fcount $>$ Ftable will be continued with the $t$ test. The $t-$ test aims to see partially the effect of the independent variables on organizational culture (X1), motivation (X2), and work discipline (X3) on the performance of employees at the Forest Area Stabilization Center Region I Medan. -t test (Partial Test) which is to test whether there is an effect of the independent variable $(\mathrm{X})$ partially on the dependent variable $(\mathrm{Y})$.

\subsection{Coefficient of Determination Analysis}

The coefficient of determination (R2) means measuring how far the model's ability to explain variations in the dependent variable is. The small value of $\mathrm{R} 2$ means that the ability of the independent variable in explaining the dependent variable is very limited. The value of R2 which is close to 1 means the ability of the independent variable to provide all the information needed to predict the variation of the dependent variable simultaneously.

\section{Result and Discussion}

4.1. Validity Test

Validity test is used to measure the validity or validity of a questionnaire. The instrument used in the form of a questionnaire that was tested on 57 respondents, employees of the Center for the Stabilization of Forest Areas Region I Medan. This validity test is carried out by comparing the values of rcount and rtable for each of the existing statement items. If the value of rcount $>$ rtable, then the item of the instrument is said to be valid. The method used in testing the validity uses a product moment correlation approach with the provisions of instrument validity if rcount $>$ rtable at $\mathrm{N}=57$. So that the $\mathrm{r}$ table value is 0.26 . Validity test results can be seen from the following table:

Table 2. Test the Validity of Organizational Culture Instruments (X1), Motivation (X2), Work

\begin{tabular}{cccccc} 
& \multicolumn{5}{c}{ Discipline $(\mathrm{X} 3)$ and Performance $(\mathrm{Y})$} \\
\hline $\begin{array}{c}\text { No } \\
\text { Question }\end{array}$ & $\begin{array}{l}\text { r-count } \\
(\mathrm{X} 1)\end{array}$ & $\begin{array}{l}\text { r-count } \\
(\mathrm{X} 2)\end{array}$ & $\begin{array}{l}\text { r-count } \\
(\mathrm{X} 3)\end{array}$ & $\begin{array}{l}\mathrm{r} \text {-count } \\
(\mathrm{Y})\end{array}$ & $\mathrm{r}$ table \\
\hline 1 & 0.571 & 0.769 & 0.400 & 0.480 & 0.26 \\
2 & 0.392 & 0.829 & 0.698 & 0.364 & 0.26 \\
3 & 0.425 & 0.396 & 0.699 & 0.400 & 0.26 \\
4 & 0.533 & 0.367 & 0.330 & 0.499 & 0.26 \\
5 & 0.314 & 0.832 & 0.454 & 0.535 & 0.26 \\
6 & 0.692 & 0.329 & 0.597 & 0.586 & 0.26 \\
7 & 0.764 & 0.671 & 0.582 & 0.603 & 0.26 \\
8 & 0.522 & 0.630 & 0.458 & 0.738 & 0.26 \\
9 & 0.598 & 0.535 & 0.613 & 0.524 & 0.26 \\
10 & 0.459 & 0.829 & 0.419 & 0.538 & 0.26 \\
11 & 0.702 & 0.564 & 0.520 & 0.594 & 0.26 \\
12 & 0.747 & 0.726 & 0.581 & 0.631 & 0.26 \\
13 & 0.788 & 0.757 & 0.699 & 0.465 & 0.26 \\
14 & 0.746 & 0.377 & 0.375 & 0.672 & 0.26 \\
15 & 0.703 & 0.801 & 0.337 & 0.733 & 0.26 \\
\hline
\end{tabular}


Based on the attachment table 2, the validity test conducted on the organizational culture, motivation and work discipline variables can be seen that all the statement components in these variables are valid. It can be seen in the table above that the variables have rcount $>$ rtable. The above instrument is declared valid because it has met the requirements of rcount $>$ rtable 0.26 , so it can be concluded that the instruments of organizational culture, motivation, work discipline, and performance can be used for research purposes.

4.2. Reliability Test The results of the validity test of organizational culture variables (X1), motivation (X2), and work discipline (X3)) on the performance (Y) of the employees of the Medan Region I Forest Area Stabilization Center can be seen as follows:

Table 3. Reliability Test of Organizational Culture Instruments (X1), Motivation (X2), Work Discipline (X3) and Performance (Y)

\begin{tabular}{|c|c|c|}
\hline Variable & $\begin{array}{c}\text { Cronbach's } \\
\text { Alpha }\end{array}$ & Description \\
\hline $\begin{array}{l}\text { Organizational } \\
\text { culture }\end{array}$ & 0.905 & Reliable \\
\hline Motivation & 0.917 & Reliable \\
\hline Work Discipline & 0.865 & Reliable \\
\hline Performance & $\underline{0.890}$ & $\underline{\text { Reliable }}$ \\
\hline
\end{tabular}

In table 3 the results of the reliability test for each variable using the Cronbach's Alpha technique, it can be seen that the Cronbach's Alpha value is $>0.6$, for the organizational culture variable the Cronbach's Alpha value is 0.905 , while for the motivation variable is 0.917 , then work discipline is 0.865 and for performance of 0.890 . So, the instruments of the four variables are declared reliable because they meet the requirements of Cronbach's Alpha value $>0.6$.

4.3. Classic Assumption Test The classical assumption test used is as follows:

a. Data Normality Test

The normality test is intended to determine whether the samples taken in the study are normally distributed or not. The normality test was carried out with the one sample Kolmogorov-Smirnov Test and was said to be normal if the residual value which was normally distributed had a significance probability greater than 0.05 .

Table 3. Data Normality Test

\begin{tabular}{|c|c|c|c|c|c|}
\hline & & $\begin{array}{l}\text { X1 } \\
\text { rdized } \\
\text { l1) }\end{array}$ & $\begin{array}{c}\text { TOTAL_X2 } \\
\text { (Unstandardize d } \\
\text { Residual 2) }\end{array}$ & $\begin{array}{c}\text { TOTAL_X3 } \\
\text { (Unstandardize d } \\
\text { Residual 3) }\end{array}$ & $\begin{array}{l}\text { TOTAL_Y } \\
\text { (Unstandardize d } \\
\text { Residual 4) }\end{array}$ \\
\hline $\mathrm{N}$ & & 57 & 57 & 57 & 57 \\
\hline Normal & mean & 0.000 & 0.000 & 0.000 & 0.000 \\
\hline $\begin{array}{l}\text { Parameters, } \\
\text { B }\end{array}$ & Std. Deviation & 6.461 & 6.228 & 5.284 & 6.385 \\
\hline Most & Absolute & 0.015 & 0.002 & 0.108 & 0.084 \\
\hline
\end{tabular}




\begin{tabular}{|c|c|c|c|c|}
\hline Extreme & 0.048 & 0.065 & 0.044 & 0.054 \\
\hline Differences &,- 063 &,- 064 &,- 108 &,- 061 \\
\hline Test Statistics & 0.063 & 0.064 & 0.108 & 0.061 \\
\hline asymp. Sig. (2-tailed) & $0.456^{c}$ & $0.495^{\mathrm{c}}$ & $0.495^{c}$ & $0.266^{c}$ \\
\hline
\end{tabular}

\subsection{Linearity Test}

The linearity test was conducted by looking for the regression line equation for organizational culture variables (X1), motivation (X2), work discipline (X3), and performance variables $(\mathrm{Y})$. Based on the regression line that has been made, then the significance of the regression line coefficient and its linearity is tested by using a test for linearity at a significance level of 0.05 . The criterion in the linearity test is that two variables are said to have a linear relationship if their significance (linearity) is more than 0.05 .

\begin{tabular}{rlrrrrr} 
& & \multicolumn{5}{c}{ Table 4. Test Results Linearity } \\
\multicolumn{1}{l}{ Model } & Sum of & df & & Mean Square & F & Sig. \\
& & Squares & & & & \\
\hline 1 & Regression & 1322,146 & 3 & 440.715 & 24.308 &, $000 \mathrm{a}$ \\
& Residual & 960.907 & 53 & 18,130 & & \\
& Total & 2283,053 & 56 & & & \\
\hline
\end{tabular}

Based on the results of the linearity test between the variables of organizational culture, motivation, work discipline and performance variables in Table 4 above, it is known that the linearity significance value is 1,000 . That is, the significance value is more than 0.05 so it can be concluded that there is a linear relationship between the two variables.

\subsection{Multicollinearity Test}

Multicollinearity test is needed to determine whether there are variables that have similarities between independent variables in a regression model. If there is a correlation then it is stated that the regression model has multicollinearity problems. The multicollinearity test was carried out by looking at the tolerance value and the Variance Inflation Factor (VIF) value. If the value of VIF $<10$ means that there is no multicollinearity, whereas if the value of VIF $>10$ means that there is multicollinearity.

Tables 5. Multicollinearity Test Results

\begin{tabular}{|c|c|c|c|c|c|c|c|c|}
\hline \multirow[t]{2}{*}{ Model } & & \multicolumn{2}{|c|}{$\begin{array}{l}\text { Unstandardized } \\
\text { Coefficients }\end{array}$} & \multirow{2}{*}{$\begin{array}{c}\text { Standardized } \\
\text { Coefficients } \\
\text { Beta }\end{array}$} & \multirow[t]{2}{*}{$\mathrm{T}$} & \multirow{2}{*}{ Sig. } & \multicolumn{2}{|c|}{$\begin{array}{l}\text { Collineanity } \\
\text { Statistics }\end{array}$} \\
\hline & & B & $\begin{array}{c}\text { Std. } \\
\text { Error }\end{array}$ & & & & Tolerance & VIF \\
\hline & (Constant) & 6.350 & 8.939 & & 0.710 & 0.481 & & \\
\hline & TOTAL_XI & 0.723 & 0.134 & 0.732 & 5,403 & 0.001 & 0.433 & 2,312 \\
\hline & TOTAL_X2 & 0.033 & 0.139 & 0.032 & 1,776 & 0.815 & 0.433 & 2,311 \\
\hline & TOTAL X3 & 0.115 & 0.108 & 0.095 & 1,896 & 0.290 & 0.999 & 1.031 \\
\hline
\end{tabular}

Based on the results of the multicollinearity test in table 5 , it can be said that there is no multicollinearity, because the VIF value is < 10, organizational culture (X1) is 2,312, motivation (X2) is 2,311 and work discipline (X3) is 1,031. So it can be concluded that in this study there was no multicollinearity because the VIF value was $<10$. 


\subsection{Heteroscedasticity Test}

The heteroscedasticity test has a purpose as a tester of whether a regression model has an inequality of variance from the residuals from one observation to another observation, if it remains, it is called homoscedasticity and if it is different it is called heteroscedasticity. A good regression model is homoscedasticity or there is no heteroscedasticity. This study was to test the presence or absence of heteroscedasticity using the Glejser test. If the significant value is $<0.05$, then there is heteroscedasticity, if on the contrary the significant value is $>0.05$, then there is no heteroscedasticity.

Tables 6. Heteroscedasticity Test Results

\begin{tabular}{|c|c|c|c|c|c|}
\hline \multirow[t]{2}{*}{ Model } & \multicolumn{2}{|c|}{$\begin{array}{c}\text { Unstandardized } \\
\text { Coefficients }\end{array}$} & \multirow{2}{*}{$\begin{array}{c}\text { Standardized } \\
\text { Coefficients } \\
\text { Beta }\end{array}$} & \multirow[t]{2}{*}{$\mathrm{T}$} & \multirow[t]{2}{*}{ Sig. } \\
\hline & B & Std. Error & & & \\
\hline (Constant) & 3.983 & 2.443 & & 0.493 & 0.68 \\
\hline TOTAL_X1 & 0.011 & 0.048 & 0.007 & 0.061 & 0.98 \\
\hline \multicolumn{6}{|l|}{1} \\
\hline TOTAL_X2 & 0.003 & 0.056 & 0.067 & 0.598 & 0.59 \\
\hline TOTAL_X3 & 0.002 & 0.059 & 0.108 & 0.011 & 0.41 \\
\hline
\end{tabular}

Based on the results of the heteroscedasticity test in table 6 above, it can be said that the three independent variables, namely organizational culture (X1), motivation (X2), and work discipline (X3) have a significance value of more than 0.05 so that it can be concluded that there is no heteroscedasticity problem in regression model in this study.

4.7. Multiple Linear Regression 'Test Results

To see the regression equation between organizational culture (X1), motivation (X2) and work discipline $(\mathrm{X} 3)$ on performance $(\mathrm{Y})$ can be seen:

Tables 7. Results of the Linier Regression Equation

$\begin{array}{cc}\text { Unstandardized } & \text { Standardized } \\ \text { Coefficients } & \text { Coefficients }\end{array}$

Model

B

Std. Beta

T Sig.

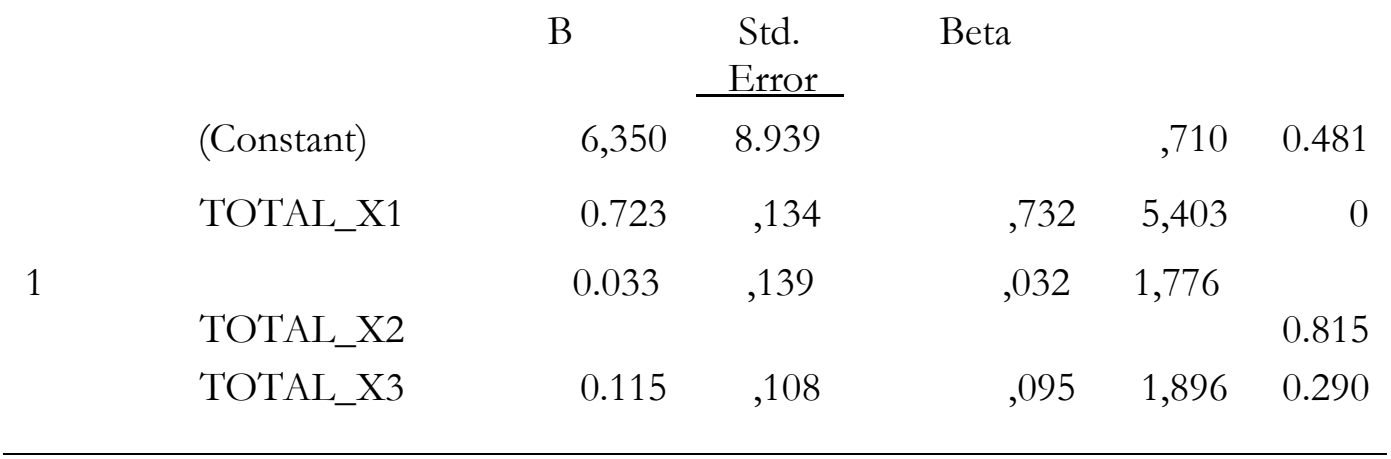

Based on Table 7 , the linear regression equation obtained is $\mathrm{Y}=6.350+0.723 \mathrm{X} 1$ $+0.033 \mathrm{X} 2+0.115 \mathrm{X} 3$ the meaning of the numbers in the above equation is as follows:

a. The regression coefficient value of the organizational culture variable is positive, namely 0.723 . This can be interpreted that every one increase in organizational culture score, it will increase performance by 0.0134 . 
b. The value of the regression coefficient of the motivation variable is positive, namely 0.033 . This means that every increase in one unit of motivation will increase performance by 0.139 .

c. The regression coefficient value of the work discipline variable is positive, which is 0.115. This means that every increase in one work discipline will increase performance by 0.108 .

\section{Conclusion}

From the results of data analysis and discussion above, several conclusions can be drawn, including: organizational culture has a positive and significant influence on employee performance at the Center for Stabilization of Forest Areas Region I Medan, the application of good culture at the Center for Stabilization of Forest Areas Region I Medan will improve performance in the organization. Motivation has a positive and significant effect on employee performance at the Forest Area Stabilization Center Region I Medan, the motivation given by company management can increase enthusiasm in working to continue to maintain its

performance in an agency. Work discipline has a positive and significant influence on the performance of employees at the Center for the Stabilization of Forest Areas Region I Medan,

\section{References}

Amelia, RP (2019). The Effect of Work Stress and Motivation on Employee Performance at Hotel Santika Premiere Ice-Bsd City. Journal of Percussion, 1(1). Berliana. (2021). The Influence of Organizational Culture on Employee Productivity at PDAM (Regional Drinking Water Company) in Jakarta. 3(2), 176-184.

Budiono, \& Erlyna. (2015). Indonesian Business Journal Vol. 6 No. October 2, 2015209. Journal

CREATIVE : Scientific Journal of Pamulang University Management Study Program, 6(3), 38. https://doi.org/10.32493/jk.v6i3.y2018.p38-48

Emm, G., Halkos, \& Bousinokis, D. (2010). The Effect of Stress and Satisfaction on Productivity. International Journal of Productivity and Performance Management., Vol.59 .(Issue: 5), 415-431. Indonesian Business, 6(2), 209-220.

Jatilaksono, Raditya Singgih. 2016. The Influence of Work Discipline and Organizational Culture on Employee Performance CV. Abank Irenk Creative Yogyakarta. Essay. Yogyakarta State University.

Jermias, J., \& Yigit, F. (2019). Factors affecting leverage during a financial crisis: Evidence from Turkey. Borsa Istanbul Review, 19(2), 171-185. https://doi.org/10.1016/j.bir.2018.07.002

Mistar, M., \& Kusumayadi, F. (2019). Impact of Compensation, Organizational Culture, Job Stress on Turnover Intention Pt. Sinarmas Multifinance Bima Branch. Jambi Journal of Accounting Research, 3(1), 65-81. https://doi.org/10.35141/jraj.v3i1.655.

Murty, Hudiwinarsih. 2012. The Effect of Compensation, Motivation and Organizational

Commitment on the Performance of Employees in the Accounting Section (Case Study in Manufacturing Companies in Surabaya). Journal of The Indonesian Accounting Review. Vol. 2. STIE Perbanas, Surabaya

Niati, D. R., Siregar, Z. M. E., \& Prayoga, Y. (2021). The Effect of Training on Work Performance and Career Development: The Role of Motivation as Intervening Variable. Budapest International Research and Critics Institute (BIRCI-Journal): Humanities and Social Sciences, 4(2), 2385-2393. https://doi.org/10.33258/birci.v4i2.1940 
Permadi, IMY (2017). Faculty of Economics and Business, Udayana University (Unud), Bali, Indonesia Increasing numbers of business players have led to competitive competition in the business world. They are required to make an innovation or changes that. 6(1), $521-549$.

Purnomo, S. (2018). The Influence of Organizational Culture, Compensation on Career Planning and Its Impact on Employee Productivity at Pt. Panca Putra Madani. Purwanta, Fatchuriza, Christina, Lenny \& Nawangasari. 2018. The Influence of Work Motivation, Organizational Culture, and Work Environment on the Work Discipline of Employees PT. Inti Karya Persada Teknik. International Journal of Scientific and

Research Publications, Volume 8, Issue 12.

Putra, GA (2021). Compensation and Work Environment: Its Effect. 3, 75-84.

Rivai, Veithzal. 2011. Human Resource Management For Companies From Theory to Practice. Jakarta: Raja Grafindo Persada.

Sayogo, Y. (2020). The concept of employee productivity of service companies in Indonesia. Researchgate, May, 1-6.

Shah, M. M., et al. (2020). The Development Impact of PT. Medco E \& P Malaka on Economic Aspects in East Aceh Regency. Budapest International Research and Critics Institute-Journal (BIRCI-Journal) Volume 3, No 1, Page: 276-286.

Simamora, Henry. 2015. Human Resource Management. YKPN School of Economics Publishing Division. Yogyakarta.

Siswanto, Bejo. 2011. Management of Indonesian Migrant Workers Administrative and Operational Approaches. Jakarta: Earth Literacy. Suroyo. (2016). Discipline that has an impact on employee productivity. Parameters, 2(001), 195.

Suwanto. 2011. Human Resource Management in Public and Business Organizations. Alphabet. Bandung. Utami, Agistina Seto and Waluyo, Handoyo Djoko. 2017. The Influence of Organizational Culture, Motivation and Work Discipline on Employee Performance at KSP Lohjinawe. Journal of Business Administration Science. Diponegoro University. Werdhiastutie, A. et al. (2020). Achievement Motivation as Antecedents of Quality Improvement of Organizational Human Resources. Budapest International Research and Critics Institute-Journal (BIRCI-Journal) Volume 3, No 2, Page: 747-752.

Widiati, Emilia. 2012. The Effect of Work Motivation, Work Discipline and Organizational Culture on the Performance of Health Employees at Panti Secanti Gisting Hospital. Journal of Masters in Management.

Widodo, Eko Suparno. 2015. Human Resource Development Management. Learning Library, Yogyakarta. Yamoah, EE (2013). Relationship between Compensation and Employee Productivity. Singaporean Journal of Business, Economics and Management Studies, 2(1), 110-114. https://doi.org/10.12816/0003845

Yuliana. (2017). The Influence of Organizational Culture, Work Discipline, Work Environment and Compensation on Employee Performance, Case Study on Permanent Employees of Age Dental Laboratory's Company Operations. Essay. Sanata Dharma University.

Zulfani, F., Agung Putu Agung, A., \& Pradiva Putra Salain, P. (2021). The Effect of Compensation, Work Stress and Organizational Culture on Turnover Intention of All Employees of PT. Andika Mitra Jaya Denpasar. Journal of Gold, 2(1), 62-70. 